DOI: https://doi.org/10.47405/mjssh.v6i9.989

\begin{tabular}{|c|c|}
\hline 4.581 & Malaysian Journal of Social Sciences and Humanities (MJSSH) \\
\hline $\begin{array}{l}\text { Malaysian Journal of } \\
\text { Social cciences and }\end{array}$ & Volume 6, Issue 9, September 2021 \\
\hline (MJ-SSH) & e-ISSN : 2504-8562 \\
\hline & $\begin{array}{l}\text { Journal home page: } \\
\text { www.msocialsciences.com }\end{array}$ \\
\hline
\end{tabular}

\title{
Faktor Risiko Jenayah Pecah Rumah dan Impak Kepada Kesejahteraan Hidup Masyarakat
}

\author{
Nur Farhana Abd Malek ${ }^{\text {, Hezzrin Mohd Pauzi¹, Normah Awang1 }}$ \\ ${ }^{1}$ Fakulti Sains Sosial Gunaan, Universiti Sultan Zainal Abidin (UNISZA) \\ Correspondence: Nur Farhana Abd Malek (farhanamalek89@yahoo.com)
}

\begin{abstract}
Abstrak
Jenayah pecah rumah merupakan suatu jenayah harta benda yang kerap terjadi dan jenayah ini sering kali dilaporkan berbanding jenayah kekerasan di Malaysia. Kegagalan melakukan pencegahan jenayah dalam mengawal permasalahan jenayah pecah rumah akan memberikan kesan kepada kesejahteraan masyarakat Malaysia. Artikel ini bertujuan untuk membincangkan mengenai faktor risiko jenayah pecah rumah dan impaknya terhadap kesejahteraan masyarakat. Kaedah kajian yang digunakan adalah berdasarkan kepada penelitian terhadap kajian-kajian lepas. Oleh itu, penelitian kajian lepas bagi faktor-faktor yang menyebabkan berlakunya jenayah pecah rumah serta impaknya terhadap kesejahteraan akan dibincangkan. Faktor kurangnya kawalan keselamatan, pemantauan pihak berkuasa PDRM dan Rukun Tetangga, serta sasaran penjenayah antara sebab berlakunya jenayah pecah rumah. Kesimpulannya, faktor-faktor berkenaan haruslah dititikberatkan supaya dapat mencegah daripada berlakunya jenayah pecah rumah. Artikel ini juga diharapkan dapat membantu pihak bertanggungjawab dalam merancang langkah pencegahan jenayah pecah rumah bagi menjamin kesejahteraan masyarakat.
\end{abstract}

Kata kunci: jenayah pecah rumah, faktor risiko, kesejahteraan masyarakat

\section{Risk Factors for Burglary and Impact on Community Well-Being}

\begin{abstract}
Burglary is a common property crime and this crime is often reported compared to violent crime in Malaysia. Failure to do crime prevention in controlling the problem of burglary will affect the wellbeing of Malaysian society. This article aims to discuss the risk factors of burglary crime and its impact on the well -being of society. The research method used is based on the review of previous studies. Therefore, a review of previous studies on the factors that lead to the occurrence of burglary crime as well as its impact on well-being will be discussed. Lack of security control, monitoring by PDRM and Rukun Tetangga authorities, as well as criminal targets are among the reasons for burglary. In conclusion, these factors should be emphasized in order to prevent the occurrence of burglary. It is also hoped that this article can help those responsible in planning measures to prevent burglary to ensure the well-being of the community.
\end{abstract}

Keywords: burglary, risk factors, community welfare 


\section{Pengenalan}

Peningkatan masalah jenayah merupakan salah satu daripada permasalahan sosial yang akan memberikan kebimbangan kepada seluruh dunia (Norita et al., 2020). Permasalahan jenayah pecah rumah sering kali terjadi dan sukar dikawal jika tiada pencegahan yang dilakukan oleh pihak berkuasa. Berdasarkan Kanun Keseksaan Akta 574 (2019), pecah rumah iaitu seseorang itu melakukan pecah rumah jika individu tersebut masuk ke dalam sesebuah rumah itu atau mana-mana bahagiannya dengan mana-mana daripada enam cara bagi melakukan suatu kesalahan. Kemudian, setelah melakukan sesuatu kesalahan di dalamnya dan ia keluar dari rumah itu atau mana-mana bahagian dengan manamana daripada enam cara iaitu:

i. Jika dia masuk atau keluar melalui suatu lubang yang dibuat olehnya, atau oleh seseorang pensubahat dalam pencerobohan rumah itu bagi maksud melakukan pencerobohan rumah itu;

ii. Jika dia masuk atau keluar melalui mana-mana lubang yang tidak dimaksudkan untuk dimasuki oleh mana-mana orang, melainkan dia atau pensubahat kesalahan itu, untuk jalan masuk bagi manusia; atau melalui mana-mana lubang yang telah dapat dimasukinya dengan jalan meniti atau memanjat mana-mana dinding atau bangunan;

iii. Jika dia masuk atau keluar melalui mana-mana lubang yang telah dibuka olehnya atau oleh seseorang pensubahat dalam pencerobohan rumah itu, bagi maksud melakukan pencerobohan rumah itu, dengan apa-apa cara yang tidak dimaksudkan untuk dibuka oleh penduduk rumah itu baginya dibuka;

iv. Jika dia masuk atau keluar dengan membuka mana-mana kunci bagi maksud melakukan pencerobohan rumah itu, atau bagi maksud keluar dari rumah itu selepas melakukan pencerobohan;

v. Jika dia dapat masuk atau keluar dengan menggunakan kekerasan jenayah atau melakukan sesuatu serangan, atau dengan mengugut hendak menyerang mana-mana orang;

vi. Jika dia masuk atau keluar melalui mana-mana lubang yang diketahuinya telah ditutup berkancing bagi menahan sesiapa masuk atau keluar dan yang telah dibuka olehnya atau oleh pensubahat dalam pencerobohan rumah itu

Sumber: Kanun Keseksaan Akta 574 (2019).

Kemudian, jenayah memberikan kesan yang lebih besar daripada apa yang masyarakat fikirkan (Farhan, 2020). Masalah jenayah pecah rumah akan memberikan pelbagai kesan terhadap kesejahteraan masyarakat. Jenayah memberikan banyak kesan kepada masyarakat yang mana bukan sahaja kepada mangsa jenayah sahaja malah setiap genap masyarakat di sesebuah kawasan (Suryati, 2016). Justeru itu, artikel ini membincangkan berkait faktor-faktor risiko yang menyumbang kepada berlakunya perlakuan jenayah pecah rumah dan kesannya kepada kesejahteraan masyarakat di Malaysia.

\section{Senario Jenayah Pecah Rumah di Malaysia}

Jenayah harta benda merupakan kategori jenayah indeks yang lebih kerap dilaporkan berlaku di Malaysia berbanding jenayah kekerasan. Masalah jenayah yang telah melanda negara bukan sahaja menyebabkan kepada kehilangan harta benda malah turut memberikan kesan kepada aspek psikologi (Norita et al., 2019). Jenayah pecah rumah juga merupakan salah satu daripada jenayah indeks di bawah kategori jenayah harta benda. Di Malaysia, jenayah indeks ini telah diklasifikasikan sebagai jenayah harta benda dan jenayah kekerasan (Polis Diraja Malaysia, 2020). Seterusnya, jenayah indeks harta benda ini juga merupakan jenayah utama yang menyumbangkan kepada kadar indeks jenayah di Malaysia (Polis Diraja Malaysia, 2020). Oleh yang demikian, trend jenayah indeks di Malaysia bagi tempoh 2015 sehingga 2020 boleh dilihat dengan jelas sebagaimana yang ditunjukkan pada Rajah 1. 
Rajah 1: Trend Jenayah Indeks keseluruhan di Malaysia bagi tempoh 2015 hingga 2020

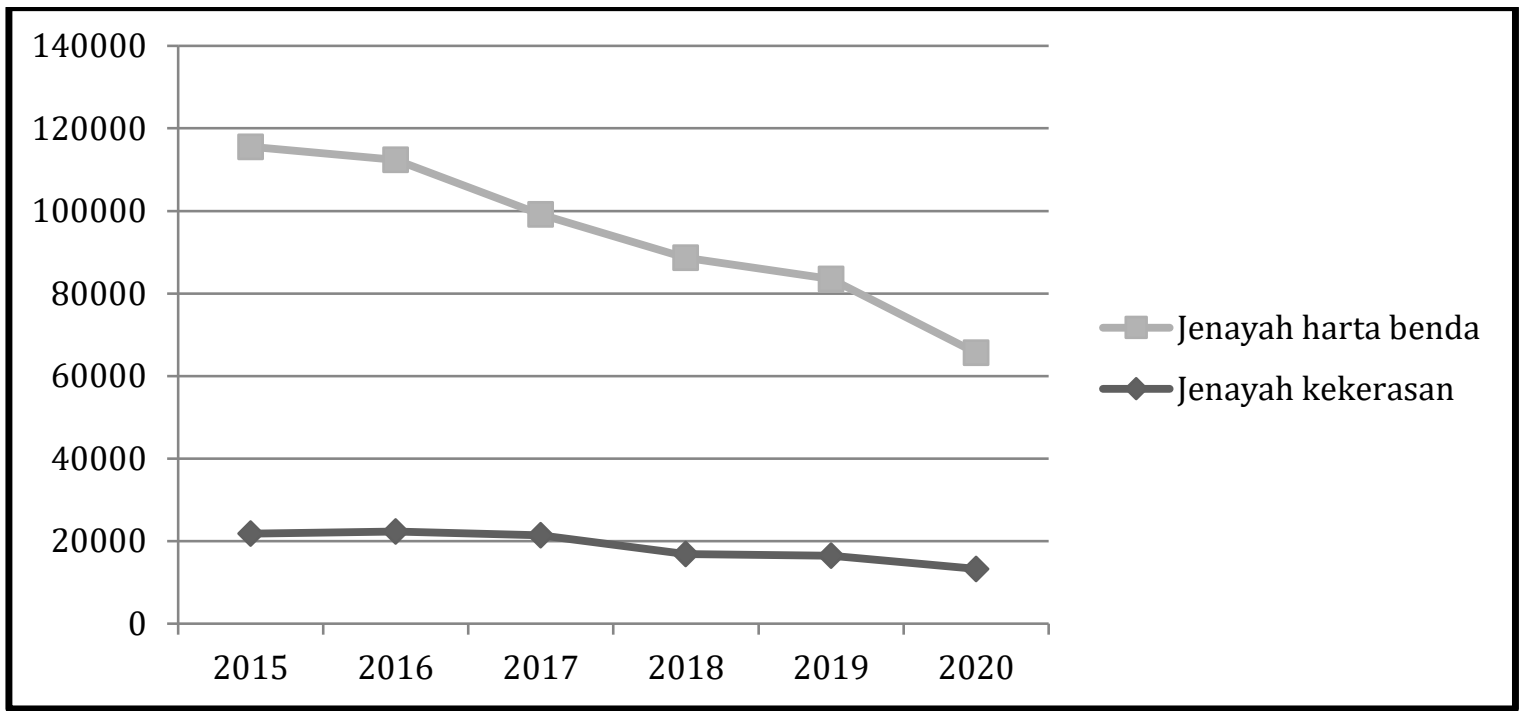

Sumber: PDRM (2020)

Berdasarkan Rajah 1 trend jenayah indeks keseluruhan di Malaysia bagi tempoh 2015 sehingga 2020, jenayah kekerasan telah mencatatkan jumlah sebanyak 112177 kes atau 19.86 peratus bagi tempoh lima tahun dari 2015 sehingga 2020. Manakala jenayah harta benda telah mencatatkan 452650 kes atau 80.1 peratus bagi tempoh yang sama. Melalui trend tersebut jelas menunjukkan bahawa jenayah harta benda mencatatkan jumlah kes yang lebih tinggi berbanding jenayah kekerasan bagi tempoh sepanjang tahun 2015 hingga 2020. Maka dapat dilihat bahawa jenayah indeks harta benda merupakan penyumbang utama indeks jenayah di Malaysia bagi tempoh tersebut.

Jadual 1: Statistik Jenayah Indeks Keseluruhan Di Malaysia 2015-2020

\begin{tabular}{lllllll}
\hline Tahun & $\mathbf{2 0 1 5}$ & $\mathbf{2 0 1 6}$ & $\mathbf{2 0 1 7}$ & $\mathbf{2 0 1 8}$ & $\mathbf{2 0 1 9}$ & $\mathbf{2 0 2 0}$ \\
\hline $\begin{array}{l}\text { Jenayah Kekerasan : } \\
\text { Bunuh }\end{array}$ & 499 & 456 & 379 & 323 & 313 & 253 \\
$\begin{array}{l}\text { Rogol } \\
\text { Samun Berkawan Bersenjata Api }\end{array}$ & 2047 & 1826 & 1835 & 1648 & 1738 & 1582 \\
Samun Berkawan Tanpa Bersenjata Api & 10718 & 10907 & 9779 & 6543 & 6058 & 4323 \\
& 14 & 18 & 3 & 9 & 8 & 5 \\
Samun Bersenjata Api & 2954 & 3463 & 4315 & 3688 & 3646 & 2992 \\
Samun Tanpa Bersenjata Api & 5516 & 5531 & 5024 & 4660 & 4714 & 4118 \\
$\begin{array}{l}\text { Mencederakan } \\
\text { Jumlah }\end{array}$ & 21810 & 22326 & 21366 & 16902 & 16494 & 13279 \\
\hline $\begin{array}{l}\text { Jumlah Keseluruhan } \\
\text { Kekerasan : }\end{array}$ & 112177 & & & & & \\
\hline Jenayah Harta Benda : & & & & & & \\
Curi & 18078 & 19894 & 19204 & 19927 & 19608 & 16725 \\
$\begin{array}{l}\text { Curi Motokar } \\
\text { Curi Motosikal } \\
\text { Curi Van/Lori/Jentera Berat }\end{array}$ & 12049 & 10607 & 8482 & 7413 & 6818 & 4599 \\
$\begin{array}{l}\text { Curi Ragut } \\
\text { Pecah Rumah }\end{array}$ & 38565 & 34754 & 31577 & 26779 & 22507 & 16059 \\
Jumlah & 3395 & 3050 & 2099 & 1761 & 1550 & 921 \\
\hline $\begin{array}{l}\text { Jumlah Keseluruhan } \\
\text { Harta Benda : }\end{array}$ & 2362 & 2963 & 240 & 138 & 0 & 0 \\
\hline Jumlah Jenayah Indeks & 19286 & 18760 & 16200 & 15742 & 16498 & 14040 \\
\hline
\end{tabular}


DOI: https://doi.org/10.47405/mjssh.v6i9.989

\section{Jumlah Jenayah \\ Indeks Keseluruhan :}

\section{Sumber: Polis Diraja Malaysia (2020)}

Berdasarkan Jadual 1, statistik menunjukkan jenayah indeks keseluruhan di Malaysia dari tahun 2015 sehingga 2020 dan dapat dilihat jenis-jenis jenayah indeks yang diklasifikasikan sebagai jenayah harta benda dan jenayah kekerasan. Statistik turut memperlihatkan jenayah indeks kekerasan terdiri daripada jenayah bunuh, rogol, samun berkawan bersenjata api, samun berkawan tanpa bersenjata api, samun bersenjata api, samun tanpa bersenjata api dan mencederakan. Manakala bagi jenayah indeks harta benda terdiri daripada jenayah curi, curi motokar, curi motosikal, curi van/lori/jentera, curi ragut dan pecah rumah. Berdasarkan Jadual 1.0 tersebut jenayah harta benda yang mencatatkan jumlah kes keseluruhan iaitu lebih daripada 100000 kes iaitu jenayah curi motosikal yang mencatatkan jumlah sebanyak 170241 kes, jenayah curi yang mencatatkan jumlah sebanyak 113436 kes dan jenayah pecah rumah yang mencatatkan sebanyak 100526 kes bagi tempoh 2015 hingga 2020.

Jadual 2: Statistik Jenayah Pecah Rumah Mengikut Negeri Di Malaysia 2015-2020

\begin{tabular}{lllllll}
\hline Tahun & $\mathbf{2 0 1 5}$ & $\mathbf{2 0 1 6}$ & $\mathbf{2 0 1 7}$ & $\mathbf{2 0 1 8}$ & $\mathbf{2 0 1 9}$ & $\mathbf{2 0 2 0}$ \\
\hline Johor & 1440 & 1475 & 1211 & 1239 & 1364 & 1273 \\
Kedah & 1499 & 1287 & 1350 & 1130 & 1138 & 980 \\
Kelantan & 893 & 682 & 570 & 699 & 929 & 626 \\
Kuala Lumpur & 1907 & 1867 & 1188 & 1104 & 1088 & 949 \\
Melaka & 445 & 544 & 567 & 591 & 681 & 487 \\
Negeri Sembilan & 998 & 1023 & 895 & 873 & 765 & 660 \\
Pahang & 795 & 719 & 794 & 861 & 718 & 604 \\
Perak & 1134 & 915 & 859 & 1023 & 1064 & 666 \\
Perlis & 102 & 85 & 87 & 54 & 111 & 155 \\
Pulau Pinang & 1150 & 917 & 868 & 855 & 1036 & 736 \\
Sabah & 1544 & 1757 & 1908 & 1881 & 1806 & 1332 \\
Sarawak & 1273 & 1540 & 1314 & 1497 & 1623 & 1946 \\
Selangor & 5805 & 5497 & 4133 & 3515 & 3679 & 3025 \\
Terengganu & 301 & 452 & 456 & 420 & 496 & 601 \\
\hline Jumlah keseluruhan & 19286 & 18760 & 16200 & 15742 & 16498 & 14040 \\
\hline
\end{tabular}

Sumber: Polis Diraja Malaysia (2020)

Berdasarkan Jadual 2, statistik menunjukkan jenayah pecah rumah mengikut negeri di Malaysia bagi tempoh dari tahun 2015 hingga 2020. Berdasarkan statistik tersebut, dapati bahawa negeri Selangor telah mencatatkan jumlah kes tertinggi dalam tempoh bagi tahun 2015 hingga 2020 iaitu sebanyak 25654 kes atau 25.5 peratus. Walau bagaimanapun, negeri Selangor mencatatkan penurunan kes dari tahun 2015 iaitu 5805 kes sehingga tahun 2018 kepada 3515 kes. Pada tahun 2020, negeri Selangor mencatatkan penurunan kes lagi kepada 3025 kes dari tahun 2019 iaitu 3679 kes. Statistik menunjukkan negeri Selangor mengalami trend penurunan dalam jenayah pecah rumah bagi tempoh tersebut. Seterusnya, negeri yang merekodkan jumlah jenayah pecah rumah terendah bagi tempoh tersebut adalah negeri Perlis iaitu sebanyak 594 kes atau 0.6 peratus. Negeri Perlis dilihat mencatatkan penurunan kes dari tahun 2015 iaitu 102 kes sehingga tahun 2018 kepada 54 kes. Tetapi mencatatkan peningkatan kes pada tahun 2019 iaitu 111 kes sehingga tahun 2020 iaitu 155 kes yang mana peningkatan ini masih tidak begitu ketara berbanding negeri lain.

Berdasarkan statistik berkenaan dapat disimpulkan bahawa jelas menunjukkan jenayah pecah rumah merupakan salah satu jenayah harta benda yang menjadi penyumbang kepada kadar jenayah indeks di Malaysia. Walaupun, indeks jenayah mengalami penurunan tetapi masyarakat masih merasakan kadar jenayah masih meningkat dan kekal sama, maka ini menyebabkan wujudnya perasaan ketakutan terhadap jenayah oleh masyarakat. Permasalahan jenayah pecah rumah yang berlaku akan menjejaskan kualiti hidup penduduk setempat di sesebuah kawasan dan ini akan mengganggu kesejahteraan hidup 
mereka (Marzilla et al., 2019). Kebanyakan kes jenayah, jenayah pecah rumah merupakan jenayah yang menjejaskan atau merosakkan keamanan hidup masyarakat. Ia juga dianggap suatu masalah utama dalam masyarakat (Farzad Jalilian et al., 2014). Kejadian jenayah sering kali berlaku di kawasan persekitaran yang lebih terbuka dan kawasan orang awam. Ketiadaan perancangan yang khusus berkait ruang di kawasan kediaman akan mengakibatkan wujudnya suatu peluang jenayah berlaku dalam kawasan kejiranan (Marlyana Azyyati et al., 2018).

Oleh yang demikian, jenayah memberikan banyak kesan kepada masyarakat yang mana bukan sahaja kepada mangsa jenayah sahaja malah setiap genap masyarakat di sesebuah kawasan. Ini kerana ketakutan masyarakat untuk menjadi sebahagian daripada mangsa jenayah itu sendiri. Polis Diraja Malaysia (PDRM) juga telah mendedahkan bahawa jumlah jenayah yang dilaporkan melibatkan jenayah harta benda adalah melebihi jenayah kekerasan di Malaysia (Suryati, 2016). Maka artikel ini bertujuan membincangkan faktor yang menyumbang kepada berlakunya jenayah indeks pecah rumah ini perlu dilihat supaya dapat menjadikan garis panduan dalam membendung jenayah ini di samping dapat meningkatkan kesedaran masyarakat mengenai jenayah pecah rumah ini. Masalah jenayah ini sememangnya akan memberikan kesan kepada kesejahteraan masyarakat juga turut akan diperlihatkan supaya dapat membuka mata pelbagai pihak berkuasa dan masyarakat mengenai isu jenayah ini jika tidak dibendung dengan baik.

\section{Faktor-Faktor Yang Menyumbang Kepada Jenayah Pecah Rumah}

Faktor risiko merupakan sebab atau akibat yang menyebabkan berlakunya jenayah pecah rumah. Faktor risiko ini memberikan suatu peluang kepada individu yang bermotivasi untuk melakukan jenayah bagi melakukan perlakuan jenayah pecah rumah ini. Menurut Teori Aktiviti Rutin oleh Cohen dan Felson (1979) yang mana menyatakan bahawa jenayah pecah rumah ini berlaku apabila suatu ruang atau tempat itu wujudnya peluang dan membolehkan penjenayah bersedia untuk menghadapi situasi itu bagi melakukan perlakuan jenayah (Marzilla et al., 2019; Faizah, 2015; Siti Rasidah \& Aldrin, 2008).

Berdasarkan teori ini terdapat tiga faktor bagi mengelakkan aktiviti jenayah ini daripada terus berlaku dalam persekitaran perumahan iaitu dengan memastikan segala barangan berharga serta rumah dalam keadaan yang selamat dan tidak terdedah dengan ancaman penjenayah, melakukan pengawalan yang kerap oleh pihak berkuasa seperti polis, kejiranan, dan sebagainya, serta sentiasa memastikan golongan yang mampu terdedah dengan aktiviti jenayah ini iaitu golongan remaja supaya tidak terjerumus dengan masalah sosial dan aktiviti jenayah yang tidak bermoral ini (Mohd Nasir et al., 2018). Maka dengan itu, kajian ini cenderung untuk melihat beberapa konsep faktor yang menyumbang kepada berlakunya masalah jenayah pecah rumah ini berdasarkan beberapa kajian lepas khususnya faktor dari segi kawalan keselamatan, pemantauan pihak PDRM dan Rukun Tetangga, dan sasaran penjenayah.

\section{Kawalan Keselamatan}

Kawalan keselamatan yang kurang merupakan salah satu daripada faktor yang mendorong kepada berlakunya suatu perlakuan jenayah pecah rumah dalam sesebuah kawasan. Kawalan keselamatan dari segi pemasangan CCTV (closed-circuit television), gril tingkap, rumah berpagar, pemasangan alat penggera keselamatan dan sebagainya sangat diperlukan bagi sesebuah kediaman. Dengan adanya ciri keselamatan tambahan sebegini dapat meningkatkan tahap keselamatan sesebuah kediaman itu daripada dicerobohi atau dimasuki oleh penjenayah. Ketiadaan ciri keselamatan tambahan sebegini ia boleh mendorong suatu perlakuan jenayah pecah rumah berlaku dengan mudah yang mana seseorang penjenayah cenderung dengan yakin untuk masuk ke kediaman yang tiada ciri keselamatan sebegini (Marzilla et al., 2019).

Ini disokong oleh Faizah et al. (2015) yang menegaskan bahawa langkah perlu dilakukan bagi memperbaiki reka bentuk suatu persekitaran bandar untuk tujuan mengurangkan masalah jenayah iaitu dengan menyediakan suatu peralatan keselamatan seperti pemasangan CCTV (closed-circuit television), butang kecemasan (panic button), cermin keselamatan, papan tanda peringatan, 
pengawasan, susun atur bandar, laluan serta kemudahsampaian pencahayaan. Bagi mewujudkan suatu bandar yang selamat usaha dalam mereka bentuk persekitaran fizikal yang dapat mencegah jenayah amat diperlukan. Sementara itu, menurut Marzilla et al. (2019) kawasan perumahan mudah untuk dimasuki oleh penjenayah akibat daripada sistem keselamatan yang lemah memberikan peluang serta risiko yang tinggi untuk menjadi sasaran kepada penjenayah pecah rumah.

Pemasangan kamera litar tertutup (CCTV) di kebanyakan bandar di Malaysia dapat membantu dalam memantau kes-kes jenayah seperti ragut, peras ugut, kecurian kenderaan, pecah rumah dan sebagainya yang mana ia dapat dipantau dengan lebih dekat (Mohamad Shaharudin et al., 2017). Selain itu, perancangan dalam melaksanakan skim komuniti berpagar dan berpengawal perlu dilaksanakan bagi mewujudkan kawasan perumahan yang selamat dan sejahtera. Skim komuniti berpagar dan berpengawal di sesebuah kawasan perumahan itu akan memberikan impak yang positif terhadap kawalan keselamatan di kawasan perumahan tersebut (Saravanan, 2015). Ini disokong oleh Norazman (2010) yang menyatakan perumahan komuniti berpagar mampu menyediakan kawalan keselamatan yang lebih baik dan menjadikan sesebuah kawasan perumahan itu lebih selamat dari sebarang jenayah, selesa dan privasi. Perumahan berpagar secara amnya lebih memfokuskan kepada keselamatan komuniti dan kawasan berkawalan ketat memandangkan kadar jenayah yang semakin meningkat.

Sementara menurut Mohammad Azuan (2019) pula, sikap masyarakat yang tidak mengambil berat berkait kawalan keselamatan kediaman mereka iaitu membiarkan pintu rumah terbuka dan tidak dikunci dengan baik merupakan penyebab utama jenayah pecah rumah itu berlaku. Pencerobohan rumah paling berisiko berlaku apabila ketiadaan tuan rumah kerana pulang ke kampung dan pada musim perayaan. Ini disokong oleh Marzilla et al. (2019) yang menyatakan bahawa ketiadaan penghuni yang boleh bertindak sebagai penghalang sebagai saksi kegiatan suspek iaitu penjenayah menyebabkan jenayah pecah rumah berlaku. Misalnya ketika penghuni keluar bekerja atau membeli belah yang mana ketika itu penghuni akan mengambil masa yang lama untuk pulang semula ke rumah. Selain itu, menurut Faizah (2015) pula menyatakan jenayah berpotensi berlaku apabila kurangnya pencahayaan di laluan pejalan kaki atau kaki lima premis perniagaan pada waktu malam dan ini akan menyebabkan kawasan tersebut suram dan cenderung memudahkan aktiviti jenayah berlaku di kawasan tersebut.

Mohd Zul Fahmi (2019) bersetuju bahawa semakin terang suatu kawasan itu maka semakin memberikan kesan baik kepada masyarakat. Ini kerana, sekiranya suatu kawasan itu tidak diterangi dengan cahaya lampu, maka kebarangkalian suatu jenayah itu untuk berlaku adalah tinggi di kawasan tersebut. Kesimpulannya, kekurangan dalam kawalan keselamatan di sesebuah kediaman itu akan mewujudkan suatu peluang bagi perlakuan jenayah pecah rumah itu berlaku. Oleh itu, masyarakat haruslah meningkatkan tingkat keselamatan di kediaman masing-masing khususnya dari segi aspek keselamatan seperti pemasangan CCTV, grill pada tingkap dan pintu, kediaman yang berpagar dan sebagainya bagi mengelakkan berlakunya kejadian jenayah pecah rumah demi menjamin kesejahteraan hidup.

\section{Pemantauan daripada Pihak PDRM dan Rukun Tetangga}

Pemantauan didefinisikan sebagai suatu perihal perbuatan atau tindakan dalam memantau sesuatu perkara (Kamus Dewan Edisi Keempat, 2020). Pemantauan dari segi kawalan dan rondaan dari pihak Polis Diraja Malaysia (PDRM) dan rukun tetangga juga sangat penting bagi mengelakkan daripada perlakuan suatu jenayah itu berlaku di sesebuah kawasan kediaman atau perumahan itu. Rondaan oleh pihak PDRM dan rukun tetangga yang kurang di kawasan perumahan dapat mendorong berlakunya perlakuan jenayah. Rondaan pihak polis yang kurang kerap akan mendorong berlakunya perlakuan jenayah yang mana rondaan hanya kadang-kadang sahaja dan kawasan yang di ronda juga tidak menyeluruh dan tertumpu hanya pada kawasan perumahan baru yang menjadi mangsa penjenayah pecah rumah sahaja di ronda. Maka ia dapat meningkatkan masalah jenayah jika tiada kawalan dan rondaan yang sepatutnya (Marzilla et al., 2019).

Menurut Jamaludin (2007) turut bersetuju bahawa program rukun tetangga yang ditubuhkan menerusi rondaan di kawasan perumahan merupakan salah satu usaha dalam membanteras kegiatan jenayah. Ini 
kerana kawasan perumahan menjadi tumpuan atau sasaran kepada suatu kegiatan jenayah. Seterusnya, agensi kerajaan seperti pihak Polis Diraja Malaysia (PDRM), JSJN, Kastam, Imigresen, AADK dan Majlis Keselamatan Negara (MKN) dapat membantu dalam membanteras masalah gejala sosial dalam penyalahgunaan dadah. Usaha dalam membanteras masalah penyalahgunaan dadah bukan sahaja terletak pada pihak kerajaan sahaja malah kerjasama daripada masyarakat juga penting dan menjamin kesejahteraan hidup bersama (Azmi, 2018).

Penyertaan yang sedikit dalam Skim Rondaan Sukarela (SRS) yang melibatkan penduduk menyebabkan hubungan efektif antara komuniti dengan pihak polis hanya berlaku dalam suatu ruang lingkup yang bersifat terbatas. Kajian dapati semakin tinggi tahap keprihatinan terhadap jenayah maka ia cenderung meningkatkan tahap penyertaan dalam Skim Rondaan Sukarela (SRS) (Zainal \& Ahmad Martadha, 2015). Ini kerana penglibatan Skim Rondaan Sukarela (SRS) oleh golongan belia dan remaja dapat membawa mereka ke arah perkara yang lebih positif dan memupuk rasa tanggungjawab sosial dalam diri mereka untuk menjaga keselamatan kawasan kediaman daripada segala ancaman jenayah ini. Ini kerana kebanyakan gejala sosial yang sering kali berlaku di kawasan perumahan atau kejiranan adalah melibatkan golongan remaja atau belia (Norwahidah \& Novel, 2016).

Kesimpulannya, pemantauan pihak berkuasa dan rukun tetangga yang lemah atau kurang di sesebuah kawasan perumahan akan cenderung meningkatkan peluang bagi berlakunya masalah jenayah di sesebuah kawasan kediaman. Maka dengan itu, kerjasama antara pihak berkuasa polis dan penyertaan masyarakat dalam Skim Rondaan Sukarela (SRS) sangat penting bagi menjamin kesejahteraan masyarakat dan khususnya dalam mengekang masalah jenayah pecah rumah supaya tidak terus menghantui kehidupan masyarakat.

\section{Sasaran Penjenayah}

Sasaran penjenayah juga mampu mendorong berlakunya perlakuan jenayah pecah rumah dan seterusnya meningkatkan masalah jenayah dalam sesebuah kawasan itu. Menurut Abdullah et al., 2018 menyatakan bahawa berdasarkan keputusan eksperimen menunjukkan bahawa kemudahan awam seperti bank, pusat komersial, restoran, pusat beribadah, kawasan perumahan dan sekolah mencatatkan keterlibatan yang tinggi bagi lokasi yang menjadi sasaran penjenayah seperti jenayah pecah rumah malam dan siang, serta samun berkawan tanpa senjata api. Tambahnya lagi, rumah ibadat menjadi sasaran penjenayah kerana tempat ibadat mempunyai ramai pengunjung dan mudah bagi suspek iaitu penjenayah untuk melakukan kegiatan jenayahnya. Menurut Lizalin dan Oliver (2020) kawasan yang menjadi tumpuan orang ramai akan menjadi sasaran penjenayah untuk melakukan jenayah harta benda adalah tinggi.

Sebaliknya menurut Siti Rasidah dan Aldrin (2008) pula, berdasarkan Teori Aktiviti Rutin, penjenayah cenderung untuk melakukan jenayah apabila terdapatnya sasaran yang menepati seperti rumah kediaman yang tidak berkunci, mempunyai kereta mewah dan harta benda yang mudah diangkut ketika aktiviti jenayah dilakukan oleh penjenayah. Ini di sokong oleh Marzilla et al. (2019) yang menyatakan bahawa wujudnya sasaran mangsa yang bersesuaian seperti rumah yang mempunyai barangan berharga seperti kereta yang mewah penyebab berlakunya jenayah pecah rumah. Tambahan pula, kawasan perumahan khususnya di kawasan bandar sering kali menjadi sasaran penjenayah (Mohd Zul Fahmi, 2019).

Sementara itu, menurut Mohd Zul Fahmi (2019) pula menyatakan bahawa ruang suatu kawasan yang tidak terhad akan menjadi sasaran penjenayah untuk melakukan jenayah. Ini kerana jika suatu kawasan itu mempunyai ruang yang terhad, kurangnya laluan bagi kenderaan dan tidak terlalu banyak pilihan maka ia akan menyebabkan penjenayah itu tidak mempunyai pilihan untuk melarikan diri akibat ruang yang terhad dan ini akan menimbulkan rasa kebimbangan kepada penjenayah itu akan ditangkap dengan mudah ketika melakukan aktiviti jenayah di kawasan tersebut. Menurut Muhamat Hamzah (2014) menyatakan bahawa berdasarkan Teori Pilihan Rasional penjenayah akan menilai dahulu tahap kawalan keselamatan, ruang, akibat yang akan diperolehnya dan peluang yang wujud di sesuatu kawasan itu sebelum melakukan aktiviti jenayahnya. 
Kesimpulannya, berdasarkan sasaran penjenayah tersebut ia akan menyebabkan masyarakat atau individu itu cenderung menjadi salah seorang daripada mangsa jenayah jika bersikap kurang peka terhadap perkara yang akan mendedahkan atau memberi peluang kepada penjenayah untuk melakukan aktiviti jenayah mereka. Oleh yang demikian masyarakat seharusnya peka akan perkara ini bagi mengelakkan diri daripada menjadi mangsa jenayah dan memastikan keselamatan diri dan harta benda terjamin sekaligus menjamin kesejahteraan hidup yang berkekalan.

\section{Kesejahteraan Masyarakat Akibat Jenayah Pecah Rumah Yang Berlaku}

Indeks Kesejahteraan Rakyat Malaysia (IKRM) dibangunkan bagi memberikan gambaran mengenai tahap kesejahteraan rakyat yang meliputi aspek ekonomi dan sosial. IKRM merupakan penambahbaikan kepada Indeks Kualiti Hidup Malaysia (IKHM) yang telah diterbitkan buat kali pertama pada tahun 1999. Sub-komposit kesejahteraan sosial pula meliputi sembilan komponen iaitu kebudayaan, alam sekitar, keluarga, tadbir urus, kesihatan, perumahan, liburan, keselamatan awam dan penyertaan sosial (Unit Perancang Ekonomi, 2013).

Menurut Frica Esther dan Ubong Imang (2019) tiada definisi khusus bagi kesejahteraan yang mana istilahnya secara umum dapat dikaitkan dengan taraf dan kualiti hidup yang merangkumi aspek ekonomi, sosial, fizikal, dan psikologi yang memberikan manfaat kepada masyarakat. Sementara, menurut (Meri Enita dan Diah Ayu, 2018) pula menyatakan kesejahteraan hidup merupakan suatu kitaran yang melibatkan beberapa perubahan aspek dalam dasar kehidupan manusia yang meningkat terhadap suatu keadaan yang lebih baik dalam suatu kelompok masyarakat, gaya hidup serta hubungan sosial. Kualiti hidup rakyat yang bertambah baik juga menunjukkan bahawa kesejahteraan rakyat yang meningkat dan maju. Azizah et al. (2014) pula menyatakan kesejahteraan secara subjektif merangkumi aspek yang lebih menyeluruh seperti pendapatan dan pengagihan, persekitaran kerja, pengangkutan dan komunikasi, kesihatan, pendidikan, perumahan, alam sekitar dan kehidupan.

Menurut Amin Khan (2015) suatu kejadian jenayah yang berlaku seperti ragut dan pecah rumah, serta kekacauan yang terjadi dalam sesebuah masyarakat itu akan mempengaruhi fikiran, perasaan serta hubungan masyarakat terhadap soal keselamatan diri. Ini kerana, masyarakat yang sejahtera adalah masyarakat yang mempunyai ciri-ciri seperti aman, makmur, senang, tenteram dan juga terpelihara daripada bencana iaitu kesusahan, gangguan dan lain-lain (M. Kamal, 2013). Masalah jenayah pecah rumah menyebabkan penduduk tempatan berpendapat bahawa sesebuah kawasan tertentu mungkin merosot dan memberi kesan kepada kualiti hidup dan seterusnya memberi kesan kepada kesejahteraan masyarakat (Marzilla et al., 2019).

Selain itu, jenayah dan perasaan takut terhadap jenayah mempengaruhi kualiti hidup rakyat yang ada kalanya melibatkan kesan yang sungguh memudaratkan. Masyarakat Malaysia semakin diancam dengan situasi dan persekitaran yang kurang selamat dengan adanya kes jenayah yang dilaporkan saban hari dan rakyat terus dicengkam dengan ketakutan dan senantiasa dalam keadaan berjaga-jaga walau di mana mereka berada (Siti Sarawati et al., 2018). Marzilla et al. (2019) bersetuju bahawa masalah jenayah harta benda khususnya jenayah pecah rumah di sesebuah kawasan perumahan akan menghasilkan persekitaran yang tidak selamat dan menimbulkan rasa takut serta kebimbangan kepada penghuninya mengenai aspek keselamatan awam khususnya kediaman dan harta benda. Secara tidak langsung, masalah pecah rumah tersebut boleh menjejaskan kualiti hidup penduduk setempat dan juga kesejahteraan hidup mereka.

Menurut Faizah (2015) perasaan ketakutan terhadap jenayah boleh menghalang masyarakat daripada pergi ke kawasan-kawasan bandar tertentu dan ada juga keadaan yang boleh membuatkan seseorang itu takut untuk keluar dari rumah mereka pada sebelah petang. Sementara itu, kewujudan jenayah merupakan satu kerugian sosial kepada masyarakat yang menetap di kejiranan yang mempunyai kadar jenayah yang tinggi dan boleh dianggap suatu kawasan "hot spot". Malah ia mampu melumpuhkan pembangunan sosial dan ekonomi secara tidak langsung menyukarkan individu untuk bergerak bebas secara selamat di kawasan kejiranan (Mohammud Nazirul, 2016). 
Di peringkat global, masalah jenayah ini sering dikaitkan dengan pertumbuhan ekonomi yang rendah yang mana keadaan ini menyebabkan individu atau pihak lain terpaksa menanggung kos yang besar dalam proses keadilan jenayah dan sistem penjara. Sementara di peringkat masyarakat ia memberikan kesan buruk kepada kejiranan dan cenderung menyebabkan masyarakat berpindah dari satu bandar ke bandar yang lain apabila kawasan kediamannya mempunyai kadar jenayah yang tinggi. Manakala, bagi individu pula ia memberikan kesan negatif dari aspek kesihatan psikologi, kehilangan pendapatan dan kos rawatan perubatan akibat menjadi mangsa jenayah (Andrew Stickley et al., 2015). Seterusnya, jenayah pecah rumah dan ragut memberikan ancaman keselamatan kepada masyarakat di kawasan kampung bandar dan menjadikan kesejahteraan serta keharmonian masyarakat terancam. Kesejahteraan juga tidak wujud apabila masyarakat merasakan mereka berada dalam keadaan yang tertekan, tidak selamat, susah, sentiasa curiga dan tidak puas hati (Mohamad Shaharudin et al., 2017).

Menurut Fatimah (2007), ramai golongan remaja sekolah yang ketinggalan dari aspek pendidikan akibat terlibat dengan masalah jenayah dan ini memberikan kesan kepada kehidupan mereka dan seterusnya gagal mencapai kesejahteraan hidup yang lebih baik apabila dewasa kelak. Mereka bukan sahaja terlibat dengan pelanggaran disiplin yang penyelesaiannya boleh dilakukan oleh pihak sekolah seperti merokok dan ponteng sekolah, malah turut terlibat juga dengan kesalahan jenayah yang melibatkan polis dan mahkamah. Oleh yang demikian, keterlibatan remaja pada peringkat awal dengan tingkah laku devian tanpa kawalan memungkinkan mereka akan terus terjebak dalam aktiviti jenayah tersebut (Siti Sarawati et al., 2018).

Kesimpulannya, masalah jenayah pecah rumah ini memberikan pelbagai kesan kepada kesejahteraan masyarakat jika pihak berkuasa dan masyarakat tidak bersama-sama dalam menanganinya. Oleh yang demikian, pelbagai langkah pencegahan kelak perlulah dibentuk dan dirancang dengan baik bagi mewujudkan kembali kesejahteraan hidup masyarakat akibat daripada masalah jenayah yang berlaku. Tanpa pencegahan jenayah yang dirancang mungkin tidak mampu mengekalkan kesejahteraan hidup masyarakat di Malaysia dan akan memberikan kesan yang berpanjangan.

\section{Kesimpulan}

Secara kesimpulannya, permasalahan jenayah pecah rumah yang berlaku haruslah diberikan perhatian yang serius oleh setiap lapisan masyarakat dan pihak berkuasa yang bertanggungjawab dalam bersama-sama membendung masalah jenayah ini daripada terus berleluasa. Hal ini kerana peningkatan dalam masalah jenayah ini dapat mengancam kesejahteraan hidup masyarakat. Masyarakat akan kekal berada dalam kehidupan yang ketidakselesaan dan tidak selamat jika persekitaran hidupnya yang dikelilingi dengan pelbagai bentuk perlakuan jenayah. Berdasarkan faktor-faktor jenayah yang dikemukakan daripada kajian lepas tersebut dapat diguna pakai oleh pihak berkuasa dalam merangka pelan tindakan bagi mencegah berlakunya masalah jenayah pecah rumah ini. Di samping itu, keterlibatan masyarakat setempat dalam menyalurkan maklumat berkait masalah jenayah ini kepada pihak berkuasa dan kerajaan amatlah diperlukan bagi mengekang jenayah ini, Perkara ini haruslah ditangani segera supaya jenayah indeks pecah rumah ini tidak mengancam secara berterusan kepada kesejahteraan hidup masyarakat di Malaysia.

\section{Rujukan}

Ab Ghani, M. A. (2019). Penggera Kecurian Pintar Berimej. Universiti Tun Hussein Onn Malaysia. Abdul Malek, A. (2018). Berpadu Menggembleng Usaha: Ahmad Zahid Pembanterasan Dadah Perlu Kerjasama Pelbagai Agensi. Kementerian Dalam Negeri, Putrajaya. https://www.moha.gov.my/index.php/ms/berita-kdn/1237-berpadu-menggembleng-usaha-ahmadzahid-pembanterasan-dadah-perlu-kerjasama-pelbagai-agensi

Abdullah, S. N. H. ., Bohani, F. A., Ahamd Nazri, Z., Jeffry, Y., Abdullah, M. A., Junoh, M. N., \& Kasim, Z. A. (2018). Pengecaman Kemudahan Awam Sekitar Lokasi Jenayah Kormesial Bersiri Di Lembah Klang Dan Kuala Lumpur Menggunakan Kaedah Gugusan K-Means. Jurnal Teknologi (Sciences \& Engineering), 45-53. 
Ali, F. (2007). Masalah Sosial Pelajar Dan Hubungannya Dengan Kemerosotan Pembelajaran. Jurnal Usuluddin, 25, 145-154.

Anak Kalang, L., \& Eboy, O. V. (2020). Penentuan corak densiti jenayah di kawasan tumpuan sekolah-sekolah menengah dalam bandar kota kinabalu menggunakan aplikasi GIS. Jurnal Kinabalu, 26(2),

197-215. https://jurcon.ums.edu.my/ojums/index.php/ejk/article/view/2772/1825

Anak Kik, F. E., \& Imang, U. (2019). Kesejahteraan Sosial Masyarakat Bandar di Kawasan Perumahan. Malaysian Journal of Social Sciences and Humanities (MJSSH), 4(6), 181-192.

Anna Malai, S. (2015). Implikasi Skim Komuniti Berpengawal ( Guarded Community) Ke Atas Perancangan Kawasan Perumahan Sedia Ada Kajian Kes: Daerah Hulu Langat (Issue September). https://doi.org/10.13140/RG.2.1.2749.0401

Eksan, M. H. (2014). Teori-Teori Perlakuan Jenayah.

Hassan, M. K. (2013). Kepimpinan Institusi Pengajian Tinggi \& Masyarakat Sejahtera: Isu dan Cabaran. 283.

Ishak, S. (2016). The Costs of Crime To the Society in Malaysia. International Journal of Business, Economics and Law, 11(3), 13-18. https://www.ijbel.com/wp-content/uploads/2017/01/ECON136.pdf

Jalilian, F., Mirzaei Alavijeh, M., Changizi, M., Ahmadpanah, M., Reza Amoei, M., \& Mostafavi, F. (2014). Factors Related to Burglary From the Perspective of Burglars: A Qualitative Study. Avicenna Journal of Neuro Psych Physiology, 1(2), 1-7. https://doi.org/10.17795/ajnpp-24260

Johar, S. S., Ani, F., Saad, S. S., Damin, Z. A., Hamzah, S., Halim, H., Abdullah, M. A., \& Ku Halim, K. H. (2018). Tingkah Laku Devian Dan Perlakuan Jenayah: Cabaran Kecenderungan Negatif Di Sebalik Kehidupan Masa Lalu Dan Kini. Universiti Tun Hussein Onn Malaysia.

Jubit, N., Masron, T., \& Marzuki, A. (2020). Spatial pattern of residential burglary. The case study: Kuching, Sarawak. Journal of the Malaysian Institute of Planners, 18(3), 190-201. https://doi.org/10.21837/PM.V18I13.785

Jubit, N., Masron, T., Nordin, M. N., \& Chabo, D. (2019). Aplikasi GIS dalam mengenal pasti kawasan hot spot jenayah harta benda di Kuching, Sarawak. Malaysian Journal of Society and Space, 15(4), 30-49. https://doi.org/10.17576/geo-2019-1504-03

Kamarulzaman, F. (2020). The effects of crime on Malaysia. https://www.emirresearch.com/theeffects-of-crime-on-malaysians/

Kamus Dewan Edisi Keempat. (2020). Pemantauan. Dewan Bahasa Dan Pustaka Malaysia. https://prpm.dbp.gov.my/Cari1 ?keyword=pemantauan\&d=175768\&

Kanun Keseksaan (Akta 574). (2019). Kanun Keseksaan (Akta 574) (Lembaga Penyelidikan Undangundang (ed.)). International Law Book Services. www.goldenbookscentre.com

Khan, A. (2015, August 3). Mencegah Jenayah Merupakan Pilihan Lebih Baik. https://www.mstar.com.my/klik/2015/08/03/pemandu-6

M, M., CR, R. A., \& S, Z. (2019). Dilema masalah jenayah pecah rumah impak pembangunan Lebuhraya Baru Pantai (NPE). Malaysian Journal of Society and Space, 15(4), 80-91. https://doi.org/10.17576/geo-2019-1504-06

Marzukhi, M. A., Afiq, M. A., Leh, O. L. H., \& Abdullah, Y. A. (2018). the Defensible Space Concept in Neighbourhood Park. Journal of the Malaysian Institute of Planners, 16(3), 274-284. https://www.planningmalaysia.org/index.php/pmj/article/view/517/421

Md Latif, F. (2015). Ke arah pengurangan indeks jenayah jalanan di Pusat Bandar Kuala Lumpur. GEOGRAFIA OnlineTM Malaysian Journal of Society and Space, 11(4), 97-107.

Md Latif, F., Nordin, N. A., \& Au-yong, C. P. (2015). Rekabentuk bagi keselamatan bandar di Kuala Lumpur: Satu ulasan kritis. Geografia-Malaysian Journal of Society and Space, 11(9), 40-53.

Md Sakip, S. R., \& Abdullah, A. (2008). Jenayah dan persekitaran : hubungan dan perkaitannya. 116.

Md Yusof, A., Ali, J., \& Kamarudin, R. (2014). Kesejahteraan Hidup Subjektif: Pengaruh Elemen Ekonomi dan Bukan Ekonomi. Prosiding PERKEM Ke-9, 9(2014), 719-727. http://www.ukm.my/fep/perkem/pdf/perkem2014/PERKEM_2014_4D4.pdf

Mohd Noh, M. N. (2016). Persepsi Kejiranan Terhadap Faktor yang Mendorong Perlakuan Jenayah. In Fakulti Geoinformasi Dan Harta Tanah. Universiti Teknologi Malaysia.

Mohd Noor, N. (2010). Keselamatan Dalam Perumahan Komuniti Berpagar. Kajian Kes - Apartment Prima Dan Taman Kristal 2, Sepang Selangor. In Fakulti Kejuruteraan Dan Sains Geoinformasi 
(Issue April). Universiti Teknologi Malaysia.

Mustaffa, J. (2007). Aspek Keselamatan Awam Dalam Pembentukan Bandar Selamat di Malaysia: Kajian Kes Alor Star, Kedah [Universiti Sains Malaysia]. Http://Eprints.Usm.My/8867/1/Aspek_Keselamatan_Awam_Dalam_Pembentukan_Bandar_Seala mat_Di_Malaysia.pdf

Polis Diraja Malaysia. (2020). Statistik Jenayah Indeks di Malaysia bagi tahun 2015 sehingga 2020.

Puspita Sari, M. E., \& Pratiwi, D. A. (2018). Faktor-Faktoryang Mempengaruhi Kesejahteraan Hidup Masyarakat Suku Laut Pulau Bertam Kota Batam. Jurnal Trias Politika, 2(2), 137-152. https://doi.org/10.33373/jtp.v2i2.1464

Sabtu, Z. A., \& Mohamed, A. M. (2015). Pelaksanaan Skim Rondaan Sukarela Dan Hubungannya Terhadap Pembentukan Modal Sosial Komuniti. Jurnal Perpaduan, 1-23. https://www.jpnin.gov.my/sites/default/files/Jurnal Perpaduan 2015_2.pdf

Samsurijan, M. S., Hussain, M. Y., Abd Manaf, A., Cr, R. A., L, N., \& MJ, M. F. (2017). Isu keselamatan dalam kesejahteraan komuniti "kampung dalam bandar" di Bandaraya Alor Setar, Kedah Darul Aman. Geografia: Malaysian Journal of Society and Space, 8(8), 112-120.

Selamat, M. N., Ibrahim, F., Nen, S., Sarnon, N., Subhi, N., Shaari, A. H., Sannusi, S. N., \& Ab Rahman, Z. (2018). Keselamatan persekitaran perumahan dalam kalangan remaja di kawasan Program Perumahan Rakyat (PPR). Malaysian Journal of Society and Space, 14(4), 115-126. https://doi.org/10.17576/geo-2018-1404-10

Stickley, A., Koyanagi, A., Roberts, B., Goryakin, Y., \& McKee, M. (2015). Crime and subjective well-being in the countries of the former Soviet Union. BMC Public Health, 15(1), 1-9. https://doi.org/10.1186/s12889-015-2341-x

Unit Perancang Ekonomi. (2013). Laporan Kesejahteraan Rakyat Malaysia 2013. In Laporan Kesejahteraan Rakyat Malaysia. http://www.epu.gov.my

Zahari, M. Z. F. (2019). Kriteria Utama Pencegahan Jenayah Menurut Perspektif Golongan Profesional Alam Bina Di Malaysia [Universiti Sains Malaysia]. https://ethesis.usm.my/jspui/handle/123456789/11367

Zinalibdin, N., \& Lydon, N. (2016). Makna rasa selamat komuniti Malaysia dalam Program Skim Rondaan Sukarela: Kajian kes KRT Taman Putera Jaya, Kota Kinabalu, Sabah. Malaysian Journal of Society and Space, 12(5), 22-32. 